\title{
Past and "pastism" in the history of psychiatry
}

I am an academic historian whose interests lie in what is called the 'early modern'. That is the period between about 1500 and 1800, during which important social and cultural transitions occurred. My last project before I retire is called Promoting modern mental health through the lessons of history. That involves podcasts, photo exhibitions, and talks in all sorts of non-academic locations, to reach a diverse range of audiences, from mental health professionals to prisoners, schoolchildren to service users.

As an academic historian I have constantly to remind myself that what we live with in the present was once in the future. We have inherited the consequences of decisions, some of which were made two centuries ago. Studying history helps us to understand why we have the institutions and attitudes that we have. More recently, we operate in the shadow of a broad trend that sits under the umbrella term of 'anti-psychiatry'. This proposes that psychiatry was much more than a medical specialty born out of humanitarianism and nineteenth century philanthropy. Rather, it was a mechanism for controlling deviant populations and was driven by the economic interests of nascent capitalism. French materialist philosopher Michel Foucault (1961/2006) is well known, German sociologist Klaus Dörner (1969/1981) less so. The views of both have been popularised in English since the 1970s by sociologist Andy Scull, whose Madness: a very short introduction (2011) encapsulates his sceptical ideas, including the anti-capitalist critique of 'big pharma'.

Interpretations of history very quickly settle into received wisdom. As an historian, my job is to revise and reinterpret. In this essay, I shall pick out some of the myths about history that serve to legitimate modern practices, while denigrating those of the past. I shall also highlight some of the more accurate perceptions that serve instead to enlighten and to facilitate change.

Several mental health history myths can be categorised as examples of "pastism": that is, the notion that everything in the past was bad, weird, or confused. One of the most prominent of these is the idea that people with mental illnesses were mistaken for witches right up until the $18^{\text {th }}$ century. Between 1500 and 1700 tens of thousands of people, mostly but not exclusively women, were executed for using knowledge of the occult to do harm. The tough thing for us to accept is that belief in witchcraft among $16^{\text {th }}$ and $17^{\text {th }}$ people was, to them, quite rational. But they also appreciated that some people suffered from mental disorders. So madness and magic sat alongside each other, but they were quite distinct. James VI and I followed Renaissance orthodoxy when he explained that witches were cunning, powerful, focused, and successful. Melancholy people, by contrast, were seen as sad, vulnerable, chaotic, and weak. Often touted as a voice of rationality in an irrational age, the Elizabethan writer Reginald Scot accepted that there were both witches and mad people: he suggested that sometimes it was possible to misidentify certain examples. Early modern people were not confused; they just inhabited a different mental world that found a place for insanity and the occult.

A similar confusion between the psychiatric and the spiritual informs the belief that people used physical interventions such as trepanation for religious reasons. Some ethnographers hypothesise that this procedure was performed in early societies to let out 
evil spirits, which were thought to be the cause of madness. This features in just about every history of psychiatry broadcast or website: I've even heard it on Melvyn Bragg's In Our Time radio programme, usually a paragon of intellectual rigour. There is, in fact, no evidence at all in British history, of surgery to release bad spirits or devils; all known trepanations were to relieve the intracranial pressure associated with head injuries.

One of the most persistent examples of "pastism" is the belief that people were put in asylums simply because they were inconvenient. Widespread institutionalisation of patients, especially paupers, began around 1800 and reached its peak a century and a half later when 150,000 people in England and Wales were institutionalised for a wide range of mental disorders, which nowadays hardly exist (general paresis of the insane), are managed in specialist facilities (severe learning disabilities) or treated in the community (like psychoses). Some sociologists see $19^{\text {th }}$ century asylums as "warehouses of the unwanted", convenient dumping grounds for inconvenient people who just did not fit in with needs of modern economies and societies (Scull, 1993:372). A variation on this claim is that husbands who could afford to pay a sympathetic doctor or madhouse keeper could have their wives put away with no just cause. A third variation on the "warehouses of the unwanted" line is that unmarried women were dumped in asylums because they had illegitimate children. There were only a few dozen cases like that in all the Scottish asylums of the Victorian period, during which tens of thousands of illegitimate children were born; institutionalised unmarried mothers had borne children and they suffered either from a pre-existing mental disorder, or one that was post-partum: they were not there simply because they were thought immoral by the standards of the day.

There is, however, a measure of truth in the "warehouses of the unwanted" approach. First, until the early $20^{\text {th }}$ century almost all asylum admissions were involuntary. Second, the lack of effective drug treatments meant length of stay was much longer than in most modern in-patient facilities (years rather than weeks). But that is not the whole story. For one thing, it was quite difficult to get into an asylum. Families usually had to petition, backed up by an affidavit from a doctor and/or magistrate. Medical superintendents had to decide who to admit, based on an assessment of the patient's condition and the chances that a stay in an institution would help them. There were always far more applications for admission than there were places. Psychiatrists prided themselves not on incarcerating and forgetting, but treating and then discharging those they had cured. Private asylum keepers, of whom there were many prior to the early $20^{\text {th }}$ century, ran commercial enterprises and they were keen to preserve their reputations, both by being discreet and by ensuring admissions were sanctioned by all interested parties. Patients and their families used the asylums for help and they negotiated their way through them: admission, discharge, readmission, and so on. They had active agency rather than being submissive recipients.

Some psychiatrists of the late nineteenth and early twentieth century argued that being in an asylum was bad for people with mental health problems. Patients discharged to the care of their families were, however, commonly readmitted sooner or later. Multiple attempts to relocate patients in families and communities show the desire of physician superintendents to cure and discharge, but also the fragility of sufferers when faced with the outside world. What may be the oldest voluntary group dealing specifically with mental health in Britain, now known as Together, was founded as the Mental After-Care Association in 1879 by the chaplain of Colney Hatch Lunatic Asylum in north London. He recognised the 
problems of supporting people leaving the institution, once they returned to the community.

This brings us to the phenomenon of positive "pastism": the view that things were better in bygone days. It is difficult to sustain the idea that everything was bad when we appreciate the remarkable diversity of past practices of care. For example, historic therapies were holistic. Each individual was treated as quite distinct from any other, even when they displayed similar signs and symptoms. Medicine was an integrated system where mind and body were connected and where discrete psychiatric categories did not exist. Thus medical practice meant taking into account all sorts of personal information, which might bear on achieving a successful outcome. Influences included the conjunction of stars at birth, occupation, religious leanings, and lifestyle. This is especially important because one of the things that doing podcast interviews with specialist clinicians has taught me is that therapies over the last 20-30 years have moved away from a one-size-fits-all approach to treatment, part of the continuing reaction against bio-reductionism. This is an example where we can learn directly from history, through a more balanced appreciation of past understandings and practices.

Contrary to what some might think, the prominence of law in medical practice is not a recent development. For centuries the ultimate power to decide on a person's treatment lay with their immediate family. Where necessary, courts of law reinforced this control. Ultimate control over whether a person was mentally capable of managing their own affairs and the completely separate issue of whether they should be compelled to live in a medical institution, also lay with law courts. Indeed, until the emergence of modern professional bureaucracies in the Victorian age, people used courts extensively to structure their lives, organise their communities, and resolve their disputes. Additionally, for centuries, developments in mental healthcare have owed much to the political complexion of governments. In the early and mid-19 ${ }^{\text {th }}$ century permissive and then compulsory legislation to build county asylums and, in the late nineteenth and early $20^{\text {th }}$ century, legislation tightening up supervisory powers came out of interventionist, left-leaning administrations. In contrast, right-leaning governments were prominent in decarceration from the 1950s to the 1980s, where the desire to save money was an important driving force. Understanding local politics is also vital in explaining both the building and reform of institutions in particular places at specific times.

Did science only came to psychiatry in the mid-20 $20^{\text {th }}$ century? This is a more complex question than it looks. The introduction of functional imaging and genetics, and the promise of personalised medication does not mean there was no science in psychiatry. In the later $17^{\text {th }}$ century, doctors picked up the language of nerves, which came to replace humoral theories of the workings of body and mind. In the $19^{\text {th }}$ century the brain came to be the focus of research, seen as the organ of the mind. To penetrate the brain without surgery, theories emerged such as physiognomy (the characteristics of the face gave an insight into personality) and phrenology (the brain had localized, specific functions, which could be "read" from studying the skull). While we now regard these as 'pseudo-sciences', they were scientifically mainstream during the $19^{\text {th }}$ century and very popular with the general public. While their underlying assumptions are long discredited, they show that psychiatry in the past had a better image, when more actively in tune with scientific advances. 
Putting the science to one side, what about the therapeutic relationship? Most histories of psychiatry adopt a teleological approach, writing off the supposedly bad and looking for the roots of what is modern and good. Moral therapy is an excellent example, featuring in all the recent psychiatric textbooks I've examined. It was indeed the precursor of many of the approaches, which modern medical professionals view as best practice. Moral treatment emphasized three things: the need for a benign environment in care; the therapeutic value of being usefully occupied at work or play; and the importance of the verbal relationship between therapist and sufferer. It was not, however, a product of the $18^{\text {th }}$ century Enlightenment. Moral therapy had its roots in centuries-old traditions of religious healing: what $17^{\text {th }}$ century people called "spiritual physic". It was based on talking. Religious belief was ubiquitous in societies until relatively recently and people often tried to explain their mental turmoil in religious terms, not because it was exclusively religious, but because the experience of spiritual turmoil provided an accessible way of sharing broader mental anguish. Only in the $19^{\text {th }}$ century did some authorities start arguing that religion itself could cause madness, part of a fundamental split between religion and science that we nowadays take for granted.

Similarly, care in the community is not a modern invention. There were almost no institutional places prior to 1800 and those were more likely to be private than public. Virtually all care was in the community. Even during the heyday of asylums in the $19^{\text {th }}$ and early $20^{\text {th }}$ centuries, Scotland preferred boarding out to institutional care, not only for the mentally disordered (especially those with LD), but also for the poor and orphans. This tells us that the social and political ethos in Scotland (and Wales, by the way) was different from that prevailing in England. It also suggests that certain types of society were more accepting of the unfortunate or disadvantaged in communities. We might ask why - and whether this can be reproduced in environments where we find stigma and a lack of acceptance, or whether it is easier to achieve in communities, which are already accepting.

I began this essay in the knowledge that the value of history might not be immediately apparent. But every mental health professional spends a good deal of time with service users, making sense of the present by reference to the past: in other words, by compiling case histories, weeding out what matters from what does not, the consistent from the inconsistent, indicators from contra-indicators. Practitioners build up a plausible picture of the mental world and physical environment of their patients. In other words, they are historians. So how can mental health professionals use the skills that history teaches?

It is surely tempting to reify modern concepts and theories of mental disorder and to imagine that there is "something real, concrete, permanent and trans-historical about them" (Ion \& Beer, 2003, 238). Hardly any diagnostic terms in use today existed before 1900. Who now has heard of neurasthenia? Others that did exist meant something different. Dementia, for example, could be used to describe any degenerative mental disorder. We assume that we are at the pinnacle of scientific understanding, poised to uncover evidence of the genetic basis of many mental disorders: biomedicine triumphant. But we may be reluctant to accept that our predecessors were just as convinced of their understandings and just as committed to doing the best they could for their patients. It is only too easy to judge people, harder to understand why they used a therapy, and tougher still to accept that their reasons were as valid as our own. Many things happened in the past which we find unpalatable, but the fact that they could happen does not prove that they 
did: the past is not a theatre of horrors, but a place where people did things differently with limited resources and, often, the best of intentions.

Knowledge is contingent: if we assume anything else, we risk ceasing to develop. We all have a place in time: we are the precipitates of a deep past, which is not quite past. By understanding it we gain a clearer sense of the present and a better chance of planning successfully for the future. Saying the past was worse tends to help legitimate modern practice, saying it was better is an invitation to change: in both cases we need an accurate notion of what historical experience was really like. History helps to hone an informed scepticism about the arguments around present day policy because many of the debates we regard as peculiar to the here and now are, in fact, timeless. The tension between the specific and the universal defines the practice of both history and clinical care.

Rab Houston 
Further reading

Andrews, J., 'They're in the Trade ... of Lunacy/They "cannot interfere" -they say': the Scottish Lunacy Commissioners and lunacy reform in nineteenth-century Scotland (Occasional Publication, No. 8, London, Wellcome Institute for the History of Medicine, 1998).

'The rise of the asylum in Britain'. In: Brunton, D., ed., Medicine transformed: health, disease and society in Europe, 1800-1930 (Manchester: Manchester University Press, 2004), 298-330.

'Cause or symptom? Contentions surrounding religious melancholy and mental medicine in late-Georgian Britain', Studies in the Literary Imagination 44, 2, 2011, 6391.

Bartlett, P., 'Legal madness in the nineteenth century', Social History of Medicine 14, 2001, 107-31.

Bartlett, P. and Wright, D., eds, Outside the walls of the asylum. The history of care in the community, 1750-2000 (London: Athlone Press, 1999).

Bartram, C., "Melancholic imaginations": witchcraft and the politics of melancholia in Elizabethan Kent', Journal of European Studies 33, 3/4, 2003, 203-11.

Beveridge, A., 'Relevance of the history of psychiatry to practicing clinicians', Advances in Psychiatric Treatment, 5, 1999, 46-52.

Brown, M., 'Rethinking early nineteenth-century asylum reform', Historical Journal 49, 2006, 425-452.

Busfield, J., 'The female malady? Men, women, and madness in nineteenth century Britain', Sociology 28, 1994, 259-77.

Davies, T. G., 'The Welsh contribution to mental health legislation in the nineteenth century', The Welsh History Review 18, 1, 1996, 40-62.

Dörner, K., Madmen and the bourgeoisie a social history of insanity and psychiatry trans Joachim Neugroschel and Jean Steinberg (1969. Oxford: Blackwell, 1981).

Eigen, J., Witnessing insanity. Madness and mad-doctors in the English court (New Haven: Yale University Press, 1995).

Foucault, M., M., History of madness ed. Jean Khalfa, trans Jonathan Murphy and Jean Khalfa (1961. London: Routledge, 2006).

Foyster, E., 'At the limits of liberty: married women and confinement in eighteenth-century England', Continuity and Change 17, 1, 2002, 39-62.

Hodgkin, K., Women, madness and sin in early modern England: the autobiographical writings of Dionys Fitzherbert (Aldershot: Ashgate, 2010).

Houston, R. A., 'Institutional care for the insane and idiots in Scotland before 1820', parts 1 and 2, History of Psychiatry 12, 1 and 2, 2001, 3-31, 177-97. 
'A latent historiography? The case of psychiatry in Britain (1500-1820)', The Historical Journal 57, 1, 2014, 289-310.

\section{https://arts.st-andrews.ac.uk/psychhist}

Ion, R. M. and Beer, M. D., 'Valuing the past: The importance of an understanding of the history of psychiatry for healthcare professionals, service users and carers', International Journal of Mental Health Nursing 12 (2003), 237-242.

Melling, J. and Forsythe, W., eds, Insanity, institutions and society, 1800-1914. A social history of madness in comparative perspective (London: Routledge, 1999).

Michael, P., Care and treatment of the mentally ill in North Wales, 1800-2000 (Cardiff: University of Wales Press, 2003).

Parry-Jones, W. L., The trade in lunacy: a study of private madhouses in England and Wales in the eighteenth and nineteenth centuries (London: Routledge and Kegan Paul, 1971).

Philo, C., "'Not at our seaside": community opposition to a nineteenth century branch asylum', Area, 19, 1987, 297-302.

Schmidt, J., 'Melancholy and the therapeutic language of moral philosophy in seventeenthcentury thought', Journal of the History of Ideas 65, 2004, 583-601.

Scull, A. T., Museums of madness (London: Allen Lane, 1979).

The Most Solitary of Afflictions: Madness and Society in Britain 1700-1900 (London: Yale, 1993).

Madness: a very short introduction (Oxford: Oxford University Press, 2011a).

'The peculiarities of the Scots? Scottish influences on the development of English psychiatry, 1700-1980', History of Psychiatry 22, 4, 2011, 403-15.

Suzuki, A., Madness at home: the psychiatrist, the patient, and the family in England, 18201860 (Berkeley: University of California Press, 2006).

Vandermeersch, P., 'The victory of psychiatry over demonology: the origin of the nineteenth-century myth', History of Psychiatry 2, 1991, 351-63.

Wootton, D., Bad medicine: doctors doing harm since Hippocrates (Oxford: Oxford University Press, 2006).

Wright, D., 'Getting out of the asylum: understanding the confinement of the insane in the nineteenth century', Social History of Medicine, 10, 1997, 137-155.

Wright, D. and Digby, A., eds, From idiocy to mental deficiency: historical perspectives on people with learning disabilities (London: Routledge, 1996). 